\title{
Calculation Of Fuel Consumption Through Flowmeter On The Ship Based On ASTM-IP Tables
}

\author{
B Wahyudi ${ }^{1}$, I Fahcruddin ${ }^{2}$, D Fitrial ${ }^{3}, \mathrm{~N} \mathrm{Almuzani}^{4}$ \\ \{bambangwahyudi23@gmail.com ${ }^{1}$, fahrudinuin@gmail.com², dnyfr1@gmail.com ${ }^{3}$, \\ nafistip72@gmail.com $\left.{ }^{4}\right\}$
}

STIP Jakarta, Jakarta, Indonesia ${ }^{1,2,3,4}$

\begin{abstract}
Ship operating costs are dominated by fuel oil purchases. Furthermore, monitoring of fuel consumption on ships is less noticed, because of the officer concerns on how the ship can move to the destination. The purpose of this research is which knowing the correction that must be done and the impact of fuel oil consumption through flowmeter in ship is corrected using ASTM-IP. The subject of this research is four ships at PT. S. I. Ship Management with specific gravity (SG) of 0,9601 . The results of the study showed that the output data flowmeter on the parent machine should be multiplied by the factor for reducing the volume to 15o $\mathrm{C}$ in ASTM-IP and it impacts the accuracy in the reporting of fuel consumption. As a result, operational costs are reduced and shipping companies sell their services competitively.
\end{abstract}

Keywords: Fuel oil consumption, correction, flowmeter

\section{Introduction}

The energy expenditure budget is in the top three positions in the monthly shopping list of shipping companies, so that, its fluctuations must be tightly guarded because of its enormous influence on the efficiency of production costs. With changes in the prices of energy raw materials in Indonesia, the reaction is very sensitive for industry players. In addition, the lack of understanding and application of good energy management also greatly affects the efficiency of energy consumption.

One of the important components that drive the ship is fuel oil. Oil fuel is used to drive a diesel engine so as to produce the driving force of the ship's propulsion. The fuel needed by a diesel engine is obtained from an oil supplier by buying it, where the fuel is sent to the ship in the port through a tank car or sent to the ship when the ship is at sea using barge facilities. The fuel purchased by the shipping company is the ship's operational cost which is in the range of $70 \%$ of the vessel's operating costs. Therefore, all shipping companies should always supervise the fuel consumption on their ships, strictly and inherently so that there is no waste of fuel consumption[1].

The results of preliminary studies conducted by researchers during the ship, in the fleet and operations section, obtained a lot of fuel monitoring problems. The obstacle that is often encountered is that the supervisors in the office concentrate more on how the ship can operating, arrive at their destination on time and safely while monitoring fuel consumption in detail on the 
ship is not done, especially fuel after going through the flow meter. This results the ship that being monitored inefficient in fuel consumption so that in the future it will disrupt the company's finances in operating the vessel.

\section{Literature Review}

In the world of shipping, oil fuels used include HFO, MFO, and IFO [2]. MFO is BBM which is not a type of distillate but includes a type of residue that is thicker at room temperature and solid black. This type of oil has a high level of viscosity compared to diesel oil. Good MFO quality must meet the limits of the properties listed in specifications in all weather conditions. Because in general MFO fuel can only be pumped and atomized after first heating. The use of this type of fuel is generally for direct combustion in large industries and is used as fuel for steam power stations and the price is cheaper than HFO.

In this study, it is assumed that the calculation of MFO fuel consumption is only used for the main engine only and does not include the loss of MFO fuel used the auxiliary machine and steam boilers. Effective Power or Brake Horse Power (BHP) is a parameter that shows the engine's ability to generate power in various operating conditions given in units of $\mathrm{kW}$. Specific Fuel Oil Consumption (SFOC) is an engine performance parameter that is related to the economic value of a machine because by knowing this, the amount of fuel needed to produce a certain amount of power in a certain time interval can be calculated. Specific fuel consumption (SFOC) can be calculated using the following equation [3].

$$
S F O C=\frac{F O C}{B H P}
$$

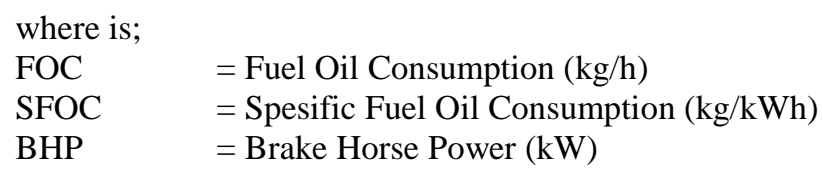

In general, the BHP value of a ship has been stated in the ship particular database of each vessel. In this study, the value of BHP used is based on 'ship particular' of tanker vessels in a shipping company in Indonesia. Based on the Specification of an 1100 TEU Container Vessels [4], SFOC on the main engine vessel for the latest engine in the 2000 era and above that has been saved is $0,176 \mathrm{~kg} / \mathrm{kWh}$. Furthermore, the SFOC value is a value at maximum $(100 \%)$ engine power. In the condition of ship operation, the use of SFOC is $85 \%$ [4] so that Equation 1 in operational conditions can be expressed by

$$
F O C_{M F O}=0,85 \times S F O C \times B H P .
$$

Flowmeter is a measuring instrument to determine the amount of fuel oil usage on the engine. The function of the Flowmeter is to measure the amount of liquid volume passing through that tool so that the amount of liquid volume that enters into a container/place or machine is obtained. To make easier to understand the position of the flow meter in the fuel oil system, the following scheme shows us about it. 


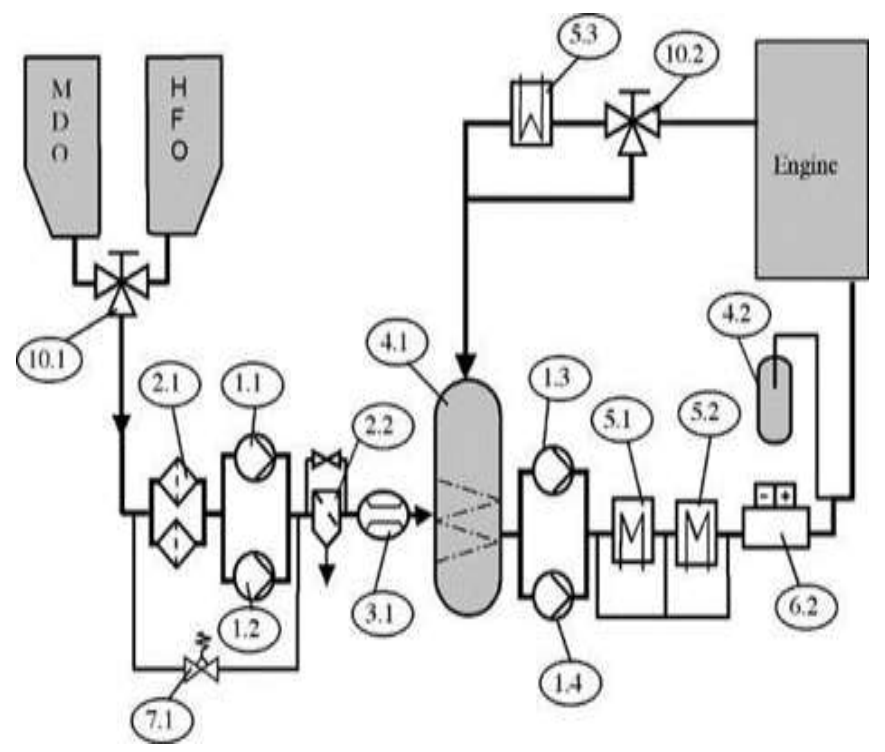

Fuel Supply Booster Module; Pos. 10.1 Change over valve Pos. 2.1 Duplex filter

Pos. 1.1, 1.2 Supply pumps

Pos. 7.1 Pressure control system

Pos. 2.2 Automatic fine filter

Pos. 3.1 Flowmeter measuring system

Pos. 4.1 Mixing + accessories

Pos. 1.3, 1.4 Booster pumps

Pos. 5.1, 5.2 HFO pre-heaters

Pos. 6.2 Viscometer sensor

Pos. 4.2 Dumping tank

Pos. 5.3 MDO cooling unit

Pos. 10.2 MDO change over valve

Figure 1: The Oil Fuel System Scheme with Flowr

Figure 1 indicates that fuel correction is not only in the tank, but more importantly, is the correction that must be made after the fuel through the flow meter, this is considering the temperature and density of fuel in the initial tank is different from the temperature and density of fuel after going through flowmeter. In order for the results of this study to be accurate, the consumption of MFO which will be corrected for its density and temperature is fuel after going through a flow meter. So, to calculate MFO fuel consumption does not need to calculate manually, just by looking at the flowmeter then making corrections to the flowmeter results using the ASTM-IP (American Society for Testing Materials the Institute of Petroleum) table.

Considering earth's material, especially liquid materials, it is very vulnerable to change due to changes in temperature, so a correction to the standards of calculation of fuel consumption must be carried out and then standardize throughout the world. The temperature used as a reference for standardization is $150 \mathrm{C}$. So wherever the location in calculating fuel consumption, it must be converted to a temperature of $150 \mathrm{C}$, in order to not harm the other party.

The standard measurement table used to correct the density and temperature of the BBM on board is the ASTM-IP table. In the table, there is a volume correction value that is used to convert oil cargo if there is a difference in temperature and density of oil on the ship. The purpose of this study is to determine the corrections that must be made and the impact of the consumption of fuel oil through the flowmeter on the ship is corrected using the ASTM-IP.

\section{Method}

The type of research used is quantitative descriptive analysis. The research subjects were several ships of PT. S. I. SHIP MANAGEMENT where the crew in the ship did not make corrections when reporting fuel oil consumption. The process of selecting subjects and stages in this study is presented in the following diagram. 


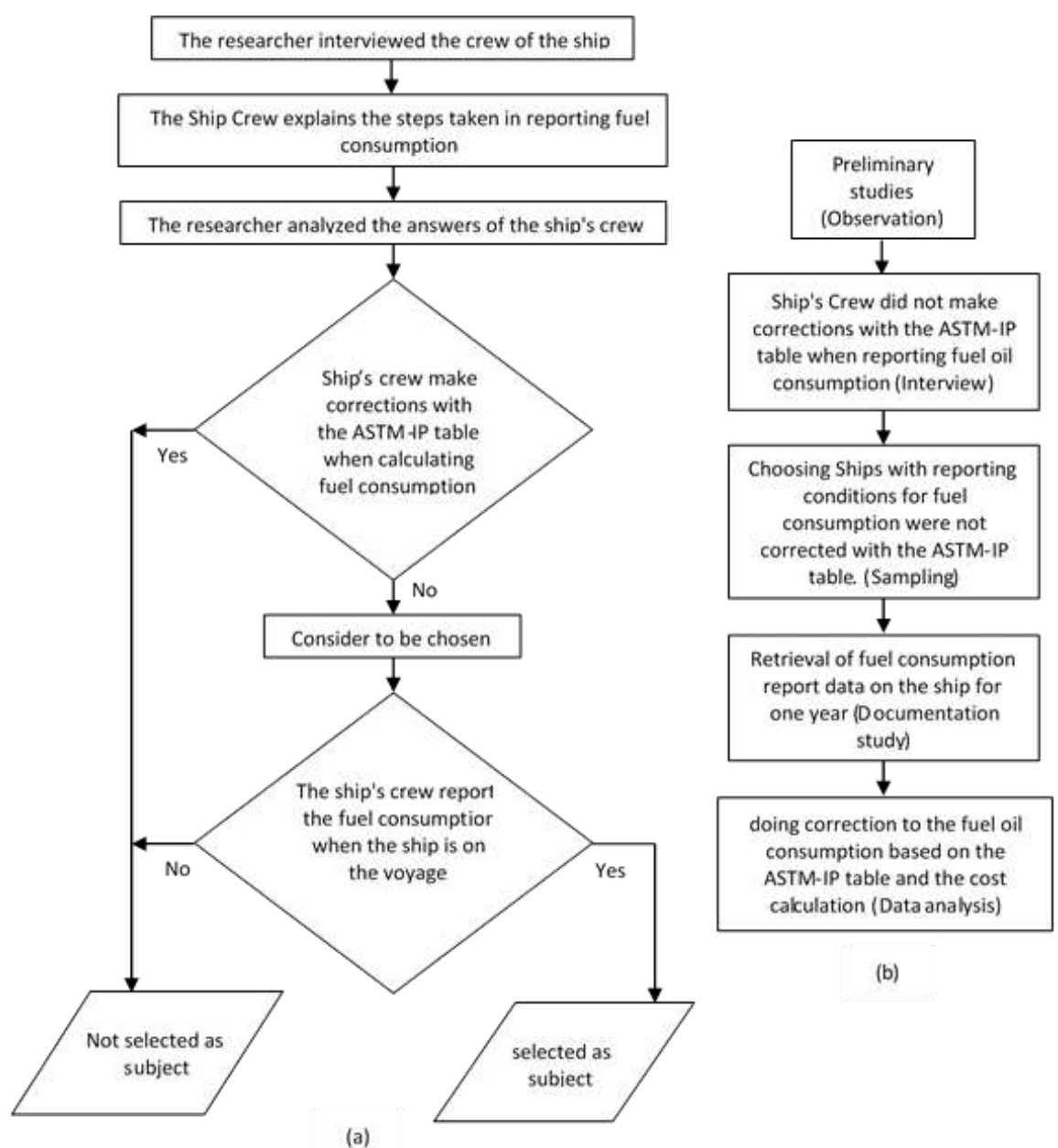

Figure 2: (a) subject selection diagram and (b) research stages

\section{Result and Discussion}

Based on the selection stage of the research subject, four vessels indicated that they did not do correction to temperature and density when reporting fuel consumption, namely:

Table 1: Research subjects

\begin{tabular}{clrl}
\hline NO & SHIP'S NAME & GRT & \multicolumn{1}{c}{ ENGINE TYPE } \\
\hline 1 & MV. SIKUD & 7.717 & MAKITA- MITSUI MAN B\&W 3939 KW \\
\hline 2 & MT. SIMAS & 13.960 & YICHANG MAN B\&W 4900 KW \\
\hline 3 & MT. SITO & 1.942 & AKASAKA 2059 KW \\
\hline 4 & MV. SIKUT & 33.348 & STX MAN 9480 KW \\
\hline
\end{tabular}

The researcher corrected the temperature and density in calculating fuel consumption on the four ships chosen to be the subjects of the study. Then the results of the correction are compared 
with the initial report, as well as calculating the cost of purchasing MFO fuel. Furthermore, the researchers make the chart of fuel consumption before and after correction to make it easier to describe the results of calculating fuel consumption. Farther, the researcher makes the bar chart for the cost of purchasing MFO fuels before and after being corrected by the ASTM-IP table, so that the difference between the two costs is seen.

Before calculating fuel consumption that will be corrected for density and temperature, first the fuel consumption report of the ship MV. SIKUD is presented for one year.

Table 2: MFO Fuel Consumption report of the ship MV. SIKUD before being corrected.

\begin{tabular}{|c|c|c|c|c|c|}
\hline \multirow{3}{*}{ No } & \multirow{3}{*}{ Vessel } & \multirow{3}{*}{ Month } & \multirow{2}{*}{\multicolumn{2}{|c|}{$\begin{array}{c}\text { Running Time of } \\
\text { MFO Usage }\end{array}$}} & \multirow{3}{*}{$\begin{array}{c}\text { MFO Consumption }\left(F O_{M F O}\right) \\
\begin{array}{c}\text { Actual Consumption M/E) } \\
\text { (MT/month) }\end{array}\end{array}$} \\
\hline & & & & & \\
\hline & & & hours & $\begin{array}{l}\text { total } \\
\text { days }\end{array}$ & \\
\hline \multirow{13}{*}{1} & \multirow{12}{*}{ MV. SIKUD } & Jan & 315,70 & 13,15 & 158,61 \\
\hline & & Feb & 65,00 & 2,71 & 33,99 \\
\hline & & Mar & 304,40 & 12,68 & 157,46 \\
\hline & & Apr & 326,40 & 13,60 & 166,56 \\
\hline & & May & 159,50 & 6,65 & 73,81 \\
\hline & & June & 209,80 & 8,74 & 94,43 \\
\hline & & July & 195,00 & 8,13 & 98,40 \\
\hline & & Aug & 53,20 & 2,22 & 28,90 \\
\hline & & Sept & 180,40 & 7,52 & 46,57 \\
\hline & & Oct & 208,10 & 8,68 & 113,60 \\
\hline & & Nov & 93,00 & 3,88 & 79,11 \\
\hline & & Dec & 100,00 & 4,17 & 79,03 \\
\hline & \multicolumn{2}{|c|}{ TOTAL } & $2.210,50$ & 92,10 & $1.130,47$ \\
\hline
\end{tabular}

It is known that MFO fuels of the ship MV. SIKUD has a viscosity of $180 \mathrm{cSt}$ with specific gravity of 0,9601 standardized to a density of $150 \mathrm{C}$, from Table 21 [5] obtained 0,9594 . Then the MFO is heated until reach the temperature $900 \mathrm{C}$ with a standard density of $150 \mathrm{C}$ is 0,9594 , obtained the factor for reducting volume to $150 \mathrm{C}$ from Table 54 [5] is 0,9501. Fuel consumption data through flowmeter in January amounted to 158,61 MT. So the MFO fuel consumption that has been corrected by ASTM-IP in January is $0,9501 \times 158,61 \approx 150,70$ MT. Using the same steps as the calculation of MFO consumption in January, a comparison table of MFO consumption was obtained for the condition before and after correction with the ASTM-IP table in a year. 
Table 3: MFO consumption on the ship MV. SIKUD before and after correction

MFO Consumption (MT/month)

No Vessel Month

Difference

consumption

(A - B)

$\frac{\text { Actual Consumption M/E }}{\text { NO CORRECTIONWITH CORRECTION }}$

(A)

(B)

\begin{tabular}{|c|c|c|c|c|c|}
\hline \multirow{13}{*}{1} & \multirow{13}{*}{$\begin{array}{c}\text { MV. } \\
\text { SIKUD }\end{array}$} & Jan & 158,61 & 150,70 & 7,91 \\
\hline & & Feb & 33,99 & 32,29 & 1,70 \\
\hline & & Mar & 157,46 & 149,60 & 7,86 \\
\hline & & Apr & 166,56 & 158,25 & 8,31 \\
\hline & & May & 73,81 & 70,13 & 3,68 \\
\hline & & June & 94,43 & 89,72 & 4,71 \\
\hline & & July & 98,4 & 93,49 & 4,91 \\
\hline & & Aug & 28,9 & 27,46 & 1,44 \\
\hline & & Sept & 46,57 & 44,25 & 2,32 \\
\hline & & Oct & 113,6 & 107,93 & 5,67 \\
\hline & & Nov & 79,11 & 75,16 & 3,95 \\
\hline & & Dec & 79,03 & 75,09 & 3,94 \\
\hline & & TOTAL & $1.130,47$ & $1.074,06$ & 56,41 \\
\hline
\end{tabular}

The following is a graph of the MFO consumption of the ship MV. SIKUD before and after being corrected with the ASTM-IP table.

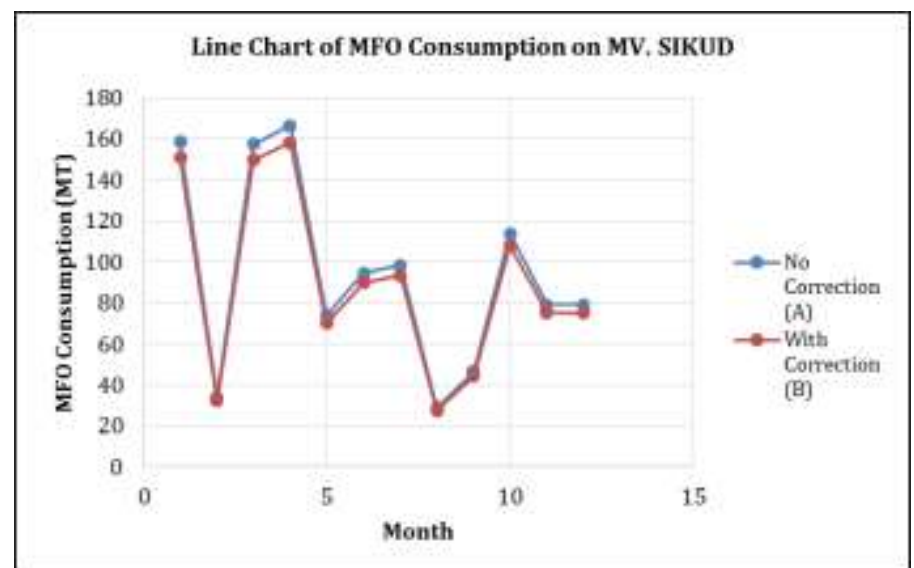

Figure 3: Line chart of MFO consumption on MV. SIKUD 
From Figure 3, it can be seen that the consumption of MFO on the ship MV. SIKUD after being corrected with the ASTM-IP table is always smaller than the consumption of MFO before being corrected by the ASTM-IP table. This is what causes the difference in reports of ship fuel residues with the results of the direct inspection on the ship where the difference is quite large (over). Furthermore, with these conditions, the correction of MFO fuel consumption will cause more efficient in using fuel.

It is known that MFO fuel prices are based on the price reference of PT. OCEAN Petro Energy period 1 - 15 February 2017, is IDR. 8,800 / Liter (including 10\% VAT and 0.3\% income tax) and does not include transportation costs to the ship. For the calculation of MFO prices per MT as follows (8.800: SG) x $1000=$ IDR. 9.165.000 / MT, not including transport costs. If the transport costs are IDR. 335 / Kg, then the price of MFO fuel oil is IDR. 9.500.000, - / MT. The following is a bar chart of the cost of purchasing MFO fuels on the ship "MV. SIKUD" before and after correction of the ASTM-IP table.

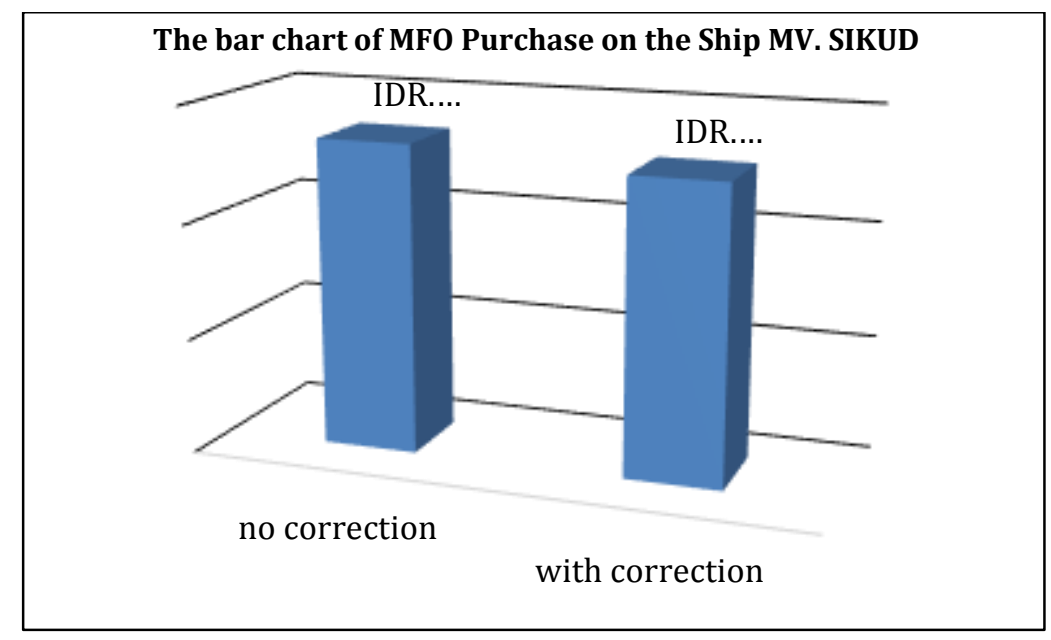

Figure 4: Bar chart of MFO purchase on the ship MV. SIKUD

From Figure 4, it can be seen that when reporting MFO fuel consumption has been corrected with the ASTM-IP table, the PT. S. I. SHIP MANAGEMENT can save the cost of purchasing MFO fuel for a year, presented in the following table.

Table 4: Savings that can be made in purchasing MFO on MV. SIKUD.

\begin{tabular}{|c|c|c|c|c|c|}
\hline \multirow{2}{*}{$\begin{array}{l}\text { MFO Prices } \\
(/ \mathrm{MT})\end{array}$} & \multicolumn{2}{|c|}{$F O C_{M F O}(\mathrm{MT} /$ year $)$} & \multicolumn{2}{|c|}{ The cost of purchasing MFO (/year) } & \multirow{2}{*}{$\begin{array}{c}\text { Difference } \\
\text { (/year) }\end{array}$} \\
\hline & $\begin{array}{c}\text { No } \\
\text { correction }\end{array}$ & $\begin{array}{c}\text { With } \\
\text { correction }\end{array}$ & No correction & With correction & \\
\hline $\begin{array}{l}\text { IDR. } \\
9.500 .000\end{array}$ & $1.130,47$ & $1.074,06$ & $\begin{array}{l}\text { IDR. } \\
10.739 .465 .000\end{array}$ & $\begin{array}{l}\text { IDR. } \\
10.203 .565 .697\end{array}$ & $\begin{array}{c}\text { IDR. } \\
535.899 .304 \\
\end{array}$ \\
\hline
\end{tabular}


By using the same calculation as the MV. SIKUD, was obtained a table of savings on MFO fuel purchase costs that can be done by PT. S. I. Ship Management, as shown by table 5, 6 and 7.

Table 5: Savings that can be made in purchasing MFO on MT. SIMAS.

\begin{tabular}{|c|c|c|c|c|c|}
\hline \multirow{2}{*}{$\begin{array}{l}\text { MFO } \\
\text { Prices } \\
\text { (/MT) }\end{array}$} & \multicolumn{2}{|c|}{$F O C_{M F O}(\mathrm{MT} /$ year $)$} & \multicolumn{2}{|c|}{ The cost of purchasing MFO (/year) } & \multirow{2}{*}{$\begin{array}{c}\text { Difference } \\
\text { (/year) }\end{array}$} \\
\hline & $\begin{array}{c}\text { No } \\
\text { correction }\end{array}$ & $\begin{array}{c}\text { With } \\
\text { correction }\end{array}$ & No correction & $\begin{array}{c}\text { With } \\
\text { correction }\end{array}$ & \\
\hline $\begin{array}{l}\text { IDR. } \\
9.500 .000\end{array}$ & $1.734,56$ & $1.648,1$ & $\begin{array}{l}\text { IDR. } \\
16.478 .358 .000\end{array}$ & $\begin{array}{l}\text { IDR. } \\
15.656 .087 .935\end{array}$ & $\begin{array}{c}\text { IDR. } \\
822.270 .064\end{array}$ \\
\hline
\end{tabular}

Table 6: Savings that can be made in purchasing MFO on MT. SITO.

\begin{tabular}{|c|c|c|c|c|c|}
\hline \multirow{2}{*}{$\begin{array}{l}\text { MFO } \\
\text { Prices } \\
(/ \mathrm{MT})\end{array}$} & \multicolumn{2}{|c|}{$F O C_{M F O}(\mathrm{MT} /$ year $)$} & \multicolumn{2}{|c|}{$\begin{array}{l}\text { The cost of purchasing MFO } \\
\text { (/year) }\end{array}$} & \multirow[t]{2}{*}{$\begin{array}{c}\text { Difference } \\
\text { (/year) }\end{array}$} \\
\hline & $\begin{array}{c}\text { No } \\
\text { correction }\end{array}$ & $\begin{array}{c}\text { With } \\
\text { correction }\end{array}$ & No correction & $\begin{array}{c}\text { With } \\
\text { correction }\end{array}$ & \\
\hline $\begin{array}{l}\text { IDR. } \\
9.500 .000\end{array}$ & 777,33 & 738,54 & $\begin{array}{l}\text { IDR. } \\
7.384 .616 .000\end{array}$ & $\begin{array}{l}\text { IDR. } \\
7.016 .123 .661\end{array}$ & IDR. 368.492 .339 \\
\hline
\end{tabular}

Table 7: Savings that can be made in purchasing MFO on MV. SIKUT.

\begin{tabular}{|c|c|c|c|c|c|}
\hline \multirow{2}{*}{$\begin{array}{l}\text { MFO } \\
\text { Prices } \\
\text { (/MT) }\end{array}$} & \multicolumn{2}{|c|}{$F O C_{M F O}(\mathrm{MT} /$ year $)$} & \multicolumn{2}{|c|}{ The cost of purchasing MFO (/year) } & \multirow{2}{*}{$\begin{array}{l}\text { Difference } \\
\text { (/year) }\end{array}$} \\
\hline & $\begin{array}{c}\text { No } \\
\text { correction }\end{array}$ & $\begin{array}{c}\text { With } \\
\text { correction }\end{array}$ & $\mathrm{Nc}$ & $\begin{array}{c}\text { With } \\
\text { correction }\end{array}$ & \\
\hline $\begin{array}{l}\text { IDR. } \\
9.500 .000\end{array}$ & $3.489,78$ & $3.315,64$ & $\begin{array}{l}\text { IDR. } \\
33.152 .891 .000\end{array}$ & $\begin{array}{l}\text { IDR. } \\
31.498 .561 .739\end{array}$ & $\begin{array}{c}\text { IDR. } \\
1.654 .329 .261\end{array}$ \\
\hline
\end{tabular}

Generally, ship crew reports related to MFO fuel consumption are $F O C_{M F O}$ before being corrected, that is meaning $F O C_{M F O}$ was reported only based on flowmeter output, did not corrected with ASTM-IP table. Furthermore, the officer also did not make corrections with the ASTM-IP table, so the losses suffered by shipping companies were very large.

The loss due to the use of MFO fuel for the main engine which is only based on the flow meter can occur because in general the supervisors in the office and the ship did not do correction to the fuel with temperature and density according to the ASTM-IP table. That's meaning, the fuel passing through the flowmeter and then consumed by the engine, should be corrected the volume indicated by the flowmeter, based on the temperature and density that has been standardized using the ASTM-IP table.

\section{Conclusion}

From the results of research and data analysis, conclusions are obtained as follows:

a. Correction of temperature and density on ship fuel that through flowmeter must be done to ensure the accuracy of fuel consumption. This can be done by multiplying the flowmeter output data by the factor for reducting volume to $150 \mathrm{C}$ that is obtained in the ASTM - IP table.

b. Corrections on reporting the calculation of ship fuel consumption can reduce the expenditure costs for buying fuel. 


\section{References}

[1] KP. Teknik, "Proposal untuk penggantian bahan bakar dari MDO ke MFO," 2007.

[2] Man B \& W, "MAN B \& W DIESEL-K90ME9-TII Project Guide - Electronically Controlled Two-Stroke Engines," Denmark, 2010.

[3] B. Baharuddin, "Perancangan Simulasi Kontrol Otomatis Distribusi Bahan Bakar Tangki Harian pada Km. Madani Nusantara," J. Adm. dan Kebijak. Kesehat. Indones., vol. 14, no. 1, pp. 61-76, 2016.

[4] A. Bruegge, Specification of a 1100 TEU Container Vessels. Hamburg: Vega Reederi GMBH \& Co KG, 2004.

[5] ASTM-IP, "American Society for Testing Material the Institute of Petroleum Tables," 1965. 